\title{
EXPLORING THE IMPLEMENTATION OF THE PLANNED PREVENTIVE CONSERVATION IN RURAL AREA: THE PRACTICE OF SHIFENG VILLAGE
}

\author{
Y. YANG ${ }^{1}, \mathrm{Y} . \mathrm{XU}^{1}, \mathrm{~S} . \mathrm{HE}^{1,} *$ Z. TANG ${ }^{2}$ \\ ${ }^{1}$ School of Architecture and Urban Planning, Guangdong university of technology, Guangzhou510062, China - \\ 727643516@qq.com, 553194648@qq.com, childhe@139.com \\ ${ }^{2}$ School of Architecture and Urban Planning, Tongji University, Shanghai200092, China - tangzzzk@163.com
}

KEY WORDS: Rural architectural heritage, Planned preventive protection, Chaoshan rural areas, Low-tech, Public participation.

\begin{abstract}
:
Villages have faced many crises in modern development. The architectural heritage is gradually declining in the changing social environment and is in urgent need of conservation. The research explores the methods of combining the concept of planned preventive conservation (PPC) with public participation to propose a low-tech approach of conserving rural architectural heritage, and has achieved significant outcomes in the village architectural heritage risk survey, architectural heritage monitoring and the development and use of conservation data management platform. The model has proven to be technologically and economically feasible, but still requires the support of local governments and grassroots managers for successful implementation in rural areas. Also, the way of public participation, applicability of tools and equipment, and the effectiveness of conservation need to be improved to better provide methodological guidelines for future village architectural heritage conservation practices.
\end{abstract}

\section{INTRODUCTION}

Villages in China embody the essence of rural settlement culture. Architecture carries the richness of its history and the unique value of the rural life. While modernization has brought opportunities, it has also brought new crises. Hollowness caused by the migration of the working population has led to the lack of maintenance of traditional buildings in the villages. People's desire to improve living standards has led to imposing "new village transformation", which has caused damages to the pattern of villages.

Meanwhile, the weak awareness of conservation, the lack of conservation funds and knowledge, and the lack of comprehensive and systematic planning, also put the conservation of rural architectural heritage in a challenging situation.

\section{THE CASE OF SHIFENG VILLAGE}

Shifeng Village is located in the town of Guihu, Chaoan County, Chaozhou City, Guangdong Province, with an area of 3.6 square kilometers. The distinguish value of Shifeng Village is concluded as follow: the distinctive village pattern that symbolizes the lion, exquisite ancestral temples and study halls and characteristic buildings, and renewed public space with tourism and sightseeing potential.

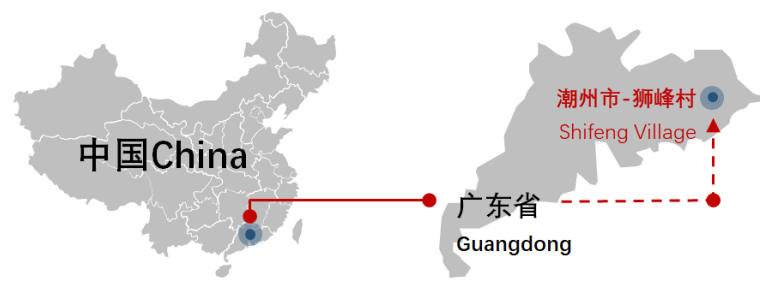

Figure 1. The location of Shifeng Village

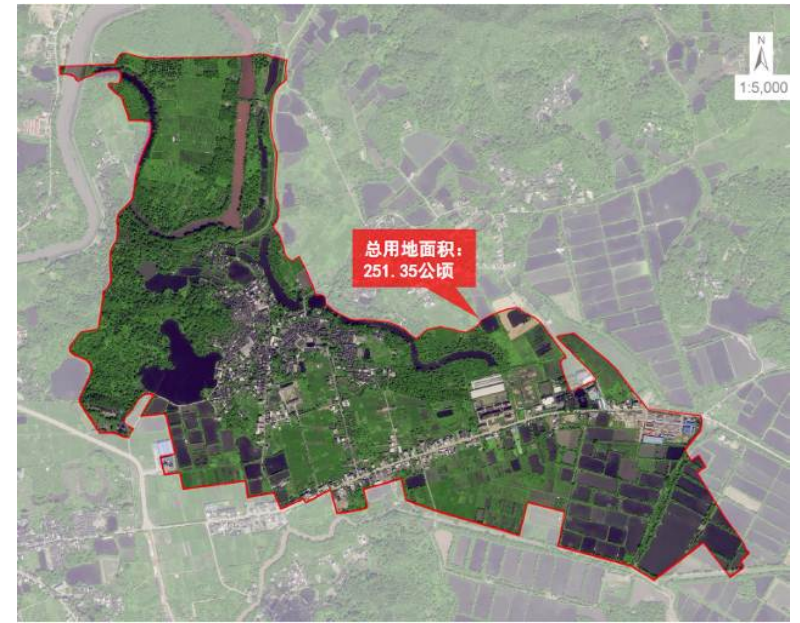

Figure 2. The map of Shifeng Village

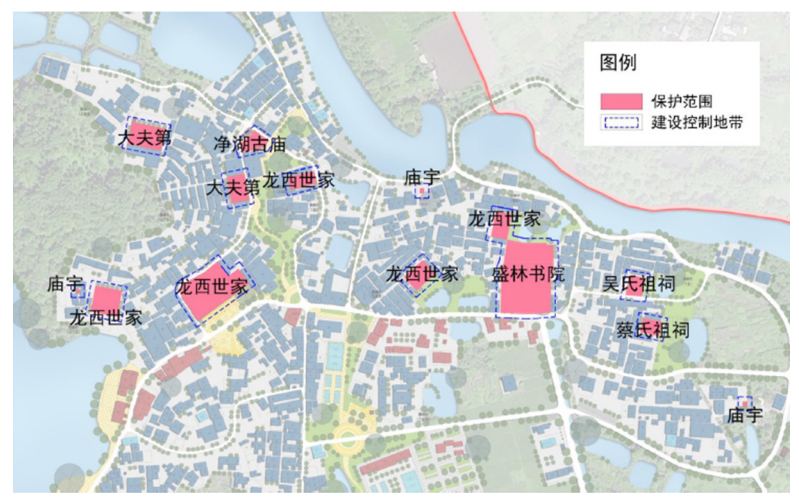

Figure 3. Architectural heritage in Shifeng Village

* Corresponding author 
Shifeng Village was once a provincial poverty-stricken village in Guangdong Province. It is a typical village in Chaoshan area with its rich culture and limited resources, which is bound to bring challenges to the conservation of architecture heritage. The challenges lies in two aspects: the diverse causes of damage, both artificial and natural, and the lack of awareness or knowledge of restoration, or the lack of restoration funds, which leads to reckless decisions or neglect.

However, what's special about Shifeng Village is that the social relations of Shifeng Village still exist and the architectural heritage is still in active use, which offers the possibility of public participation in the conservation process. The rural revitalization strategy and the support of the government also provide a benign environment for the promotion of an innovative conservation model.

In this study, we explored the method of conserving rural architectural heritage in a systematic, low-tech and effective manner, and the possibility of public participation in the conservation process.

\section{METHODOLOGY AND THEORETICAL FRAMEWORK}

The concept of Planned Preventive Conservation (PPC) is the guideline of this study. "Preventive Conservation" is an advanced concept of heritage conservation originated in the early 20th century. It proposes that a set of systematic and planned measures such as daily maintenance should be taken at the beginning of the detection of damages to keep the building functional.

So, the term "planned preventive conservation" actually suggests a two-fold meaning: "planned" and "preventive".

The "preventive" approach implies a sustainable conservation. It focuses on identifying risk factors through information collection, risk assessment and value assessment, analyzing changes in damage through regular and systematic monitoring, and reducing or eliminating risks through daily maintenance and scientific management, therefore saves the architectural heritage from destruction, and further avoid reckless restoration projects.

The "planning" approach, on the other hand, unifies the natural environment and cultural heritage in a specific geographical area within the conservation framework in a correlated form, and overlays heritage and damage distribution information in a scientific and systematic way, which makes the preventive theory operational and leads to a more macroscopic risk prevention.

In recent years, the term "planned preventive conservation (PPC)" has been widely used. It reflects the planning vision of preventive protection and covers the content of conservation under the idea of preventive conservation more comprehensively. That is, from risk assessment and prevention based on geographical and cultural characteristics in a certain area, to the maintenance, monitoring and necessary restoration of individual buildings based on value assessment and structural safety and material analysis.

Taking the problems faced by Shifeng Village into consideration, we propose the following steps for the conservation of Chaozhou's rural architectural heritage based on the PPC concept.

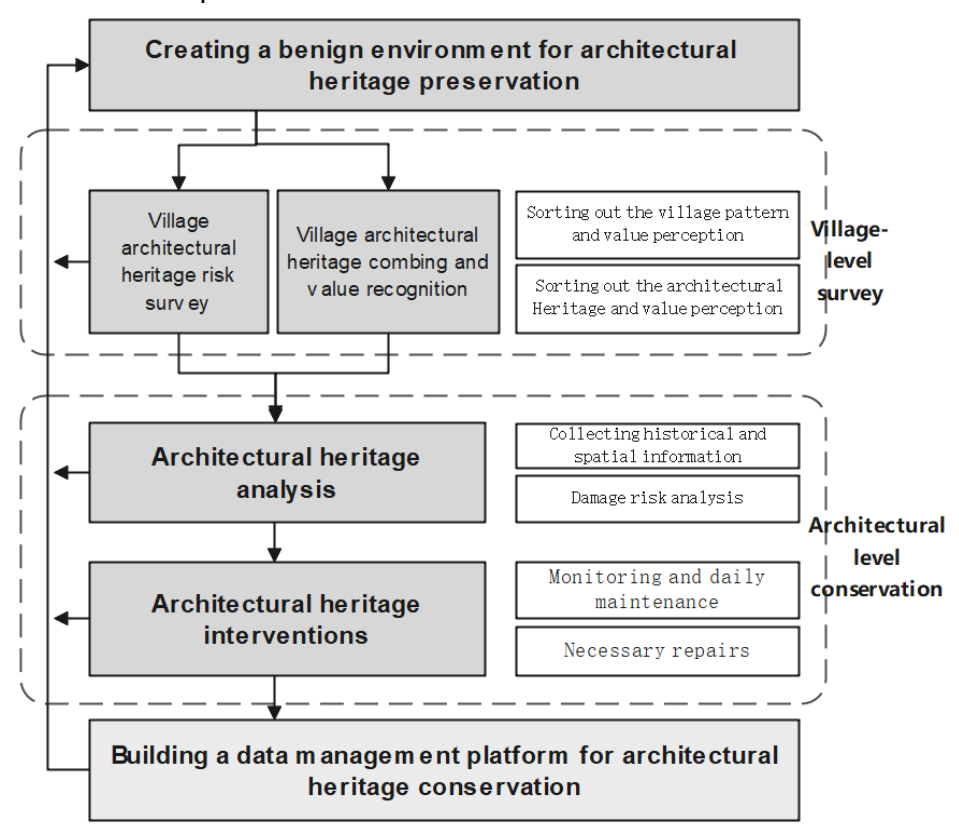

Figure 4. Steps of conservation of Chaozhou's rural

architectural heritage following the PPC concept

The economic situation of Shifeng Village demands a low-cost and highly workable conservation method. We thus proposed a model that combines public participation and low-cost practical means to explore the possibility of introducing low-tech methods in the PPC implementation.

With this goal in mind, on the one hand, we chose to use cheaper, more practical, and down-to-earth tools like smart home sensors and WeChat applet platform to reduce the cost of the equipment. On the other hand, we tried to help villagers understand the village and the condition of the buildings through simple tutorials and easy training, which later encouraged them to cooperate with experts to complete simple on-site information collection and condition reporting to reduce labor costs.

The following ideas are presented for the three steps.

\begin{tabular}{|c|c|c|c|}
\hline & $\begin{array}{l}\text { Mechanisms } \\
\text { for public } \\
\text { participation }\end{array}$ & $\begin{array}{l}\text { Low cost, } \\
\text { practical } \\
\text { and } \\
\text { effective } \\
\text { tools }\end{array}$ & $\begin{array}{c}\text { Protection } \\
\text { mode / output }\end{array}$ \\
\hline $\begin{array}{l}\text { Strategy 1: } \\
\text { Risk survey: } \\
\text { Constructing } \\
\text { an applet for } \\
\text { resident self- } \\
\text { inspection and } \\
\text { data upload }\end{array}$ & $\begin{array}{l}\text { - Resident } \\
\text { Self- } \\
\text { inspection } \\
\text { of damages } \\
\text { and } \\
\text { uploading } \\
\text { relevant } \\
\text { information } \\
\text { - Learning } \\
\text { about } \\
\text { damage } \\
\text { types, } \\
\text { causes and }\end{array}$ & $\begin{array}{l}\text { - Resident } \\
\text { self- } \\
\text { inspection } \\
\text { module } \\
\text { and } \\
\text { damage } \\
\text { upload in } \\
\text { applet }\end{array}$ & $\begin{array}{l}\text { Continuously } \\
\text { updated } \\
\text { village- } \\
\text { exclusive } \\
\text { damage atlas }\end{array}$ \\
\hline
\end{tabular}




\begin{tabular}{|c|c|c|c|}
\hline & $\begin{array}{l}\text { solutions, } \\
\text { - Receive } \\
\text { experts' } \\
\text { advice } \\
\text { remotely }\end{array}$ & & \\
\hline $\begin{array}{c}\text { Strategy 2: } \\
\text { Architecture } \\
\text { Monitoring: } \\
\text { Handing over } \\
\text { the Work of } \\
\text { Daily } \\
\text { Inspection }\end{array}$ & $\begin{array}{l}\text { - Taking } \\
\text { photos and } \\
\text { uploading } \\
\text { them with } \\
\text { phones } \\
\text { when } \\
\text { discover } \\
\text { damage in } \\
\text { architectural } \\
\text { heritage }\end{array}$ & $\begin{array}{l}\text { - Smart } \\
\text { Home } \\
\text { Sensors, } \\
\text { - Damage } \\
\text { upload } \\
\text { module in } \\
\text { applet }\end{array}$ & $\begin{array}{l}\text { - Combination } \\
\text { of remote } \\
\text { monitoring of } \\
\text { physical data } \\
\text { by experts and } \\
\text { on-site } \\
\text { observation of } \\
\text { damage by } \\
\text { villagers }\end{array}$ \\
\hline $\begin{array}{c}\text { Strategy 3: } \\
\text { Creating a } \\
\text { benign } \\
\text { environment } \\
\text { for the } \\
\text { conservation: } \\
\text { Constructing, } \\
\text { promoting and } \\
\text { utilizing the } \\
\text { data } \\
\text { management } \\
\text { platform }\end{array}$ & $\begin{array}{l}\text { - Village- } \\
\text { wide } \\
\text { sharing of } \\
\text { village } \\
\text { heritage } \\
\text { conservatio } \\
\text { n data }\end{array}$ & $\begin{array}{l}\text { Developm } \\
\text { ent and } \\
\text { use of the } \\
\text { modular } \\
\text { applet }\end{array}$ & $\begin{array}{l}\text { - A shared } \\
\text { PPC platform } \\
\text { with } \\
\text { generalized } \\
\text { knowledge } \\
\text { and visualized } \\
\text { data }\end{array}$ \\
\hline
\end{tabular}

Table 1. Strategies proposed in this article

\section{EXPLORING THE PUBLIC PARTICIPATION STRATEGIES IN THE IMPLEMENTATION OF PPC : PRACTICE IN SHIFENG VILLAGE}

\subsection{Public Participation in Risk survey: Constructing an applet for resident self-inspection and data upload}

The approach of public participation was integrated into the macroscopic risk survey for the architectural heritage of Shifeng Village. Inspired by the "Monument Damage Diagnostic System" (MDDS) and the Italian risk map, we built a participatory applet for investigating the architectural damage of Shifeng Village based on a WeChat. The applet contains the following two modules.

4.1.1 Damage self-inspection module: A typical damage diagnosis atlas of the village is created, and a three-step query mode of "building material - damage type - damage details" is designed based on the map. When villagers spot a damage, they can follow the guidelines on the applet, compare the real situation with the damage characteristics and other information described in the page, and find out the type and cause of the damage according to the map to ask for further suggestions.

4.1.2 Damage upload and remote consultation module: Villagers upload information of the damage by photographing it, recording the location, material, description of the relevant status and the contact information of the finder, in order to obtain remote consultation from experts and provide more professional advice.

The content in the diagnostic atlas will also be updated according to the information uploaded by local villagers, forming a set of exclusive damage database with local characteristics and dynamic updates. The locations of the damages will be aggregated automatically to generate the Shifeng damage map, laying the foundation for scholars to summarize the local building damage rules and explore means of damage control.
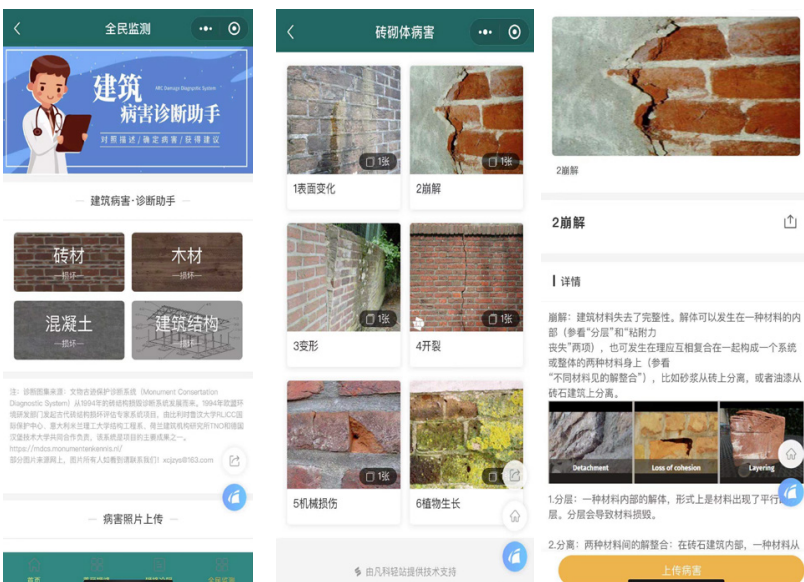

Figure 5. Damage investigation platform and Damage index directory of Shifeng Village

In order to better promote this module to villagers, we put up posters in villages to introduce each step of the practice, and set up an H5 mini-game "Go Building Defender Go" and step reminders in the app to help villagers understand the meaning and specific practices of the conservation steps.
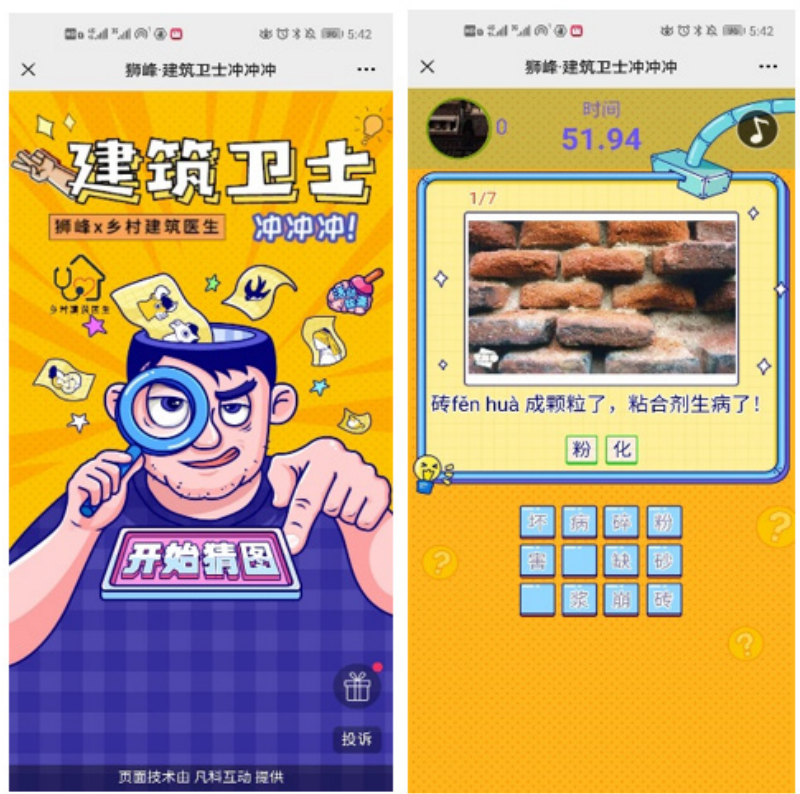

Figure 6. The H5 mini-game "Go Building Defender Go"

\subsection{Public Participation in Architecture Monitoring: Handing over the Work of Daily Inspection}

Generally, the monitoring of architectural heritage requires daily inspections by professionals to pay attention to the status of the sensors, and to carry out on-site observations to observe the signs of damage. In this project, we attempted to hand over the work of daily inspection to villagers, combining with the remote monitoring of professionals. The cooperation between professionals and villagers was aimed at avoiding potential damages caused by experts' absence and villagers' lack of knowledge about the monitoring data. 
Choosing the equipment is also crucial. Low-coat, smart home products like temperature and humidity sensors, enable users to monitor the home environment through the network of "Mobile App - Gateway - Appliance / Sensor", which we believe to have the potential to replace expensive professional sensors in the resource-constrained rural context.

Based on the early analysis, we selected Dafudi, a traditional residence at the foot of Shishan Mountain with a relatively wellpreserved form and a certain degree of damage, as the object of damage monitoring.

4.2.1 Information gathering, value analysis and risk analysis by professionals: To begin with, we purposefully collected historical information of the buildings, including information on the historical environment of the residence, restoration record, information related to the surroundings and current use and preservation information, as well as spatial information such as 3D laser scanning models, aerial modelling by drones, and photographs of the current situation.

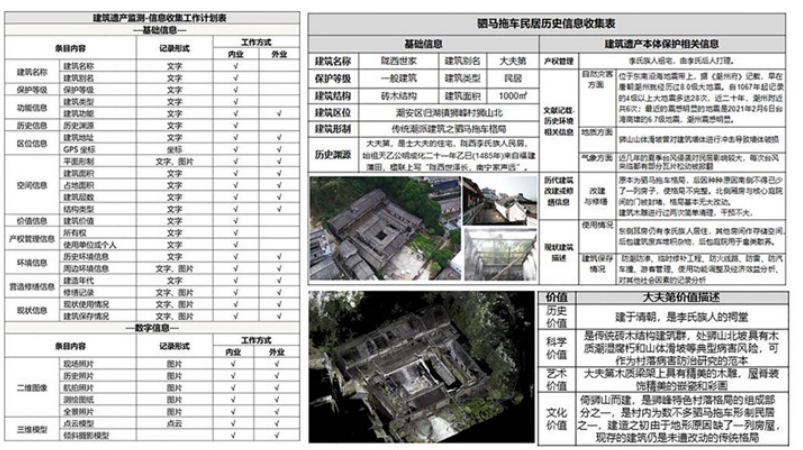

Figure 7. Architectural Information and Spatial Information of Dafudi

The results of the analysis show that the value of Dafudi mainly lies in the following aspects.

\begin{tabular}{|l|l|}
\hline VALUE & DESCRIPTION \\
\hline $\begin{array}{l}\text { Historical } \\
\text { value }\end{array}$ & $\begin{array}{l}\text { Built in the Qing Dynasty, the ancestral hall of } \\
\text { the Li clan }\end{array}$ \\
\hline $\begin{array}{l}\text { Scientific } \\
\text { value }\end{array}$ & $\begin{array}{l}\text { Traditional brick and wood structure complex, } \\
\text { located on the northern slope of Shishan } \\
\text { wood mointure decay and landslides, can be } \\
\text { used as a model for village damage control } \\
\text { research. }\end{array}$ \\
\hline $\begin{array}{l}\text { Artistic } \\
\text { value }\end{array}$ & $\begin{array}{l}\text { wooden beams with exquisite wood carvings, } \\
\text { ridge decorated with fine inlaid porcelain and } \\
\text { colorful paintings }\end{array}$ \\
\hline $\begin{array}{l}\text { Cultural } \\
\text { value }\end{array}$ & $\begin{array}{l}\text { Built against the Shishan Mountain, one of the } \\
\text { components of the characteristic village pattern } \\
\text { of Shifeng, one of the few dwellings in the } \\
\text { village in the form of Simatuoche }\end{array}$ \\
\hline
\end{tabular}

Table 1. Values of the Dafudi

Dafudi is located on the back shade of the north side of Shishan Mountain, facing north, lacking sunlight and colder all year round. The building is in traditional brick and wood structure, with a few roofs broken and collapsed. The damage of the backside rooms of the Dafudi was recorded.
4.2.2 Cooperating in the Implementation of the monitoring plan: A complete monitoring system consists of an intelligent gateway, several sensors and mobile $\mathrm{Wi}-\mathrm{Fi}$, plugs and plugs that supply network and power for it. In this study, temperature and humidity data are collected by temperature and humidity sensors distributed in the building and then transmitted to Xiaomi Gateway via Wi-Fi, which is then uploaded to the cloud server via Xiaomi Gateway network. Eventually, experts and residents can view the data measured by the sensors at each location remotely through the APP.

In the monitoring of the Dafudi, the monitoring focused on the backside rooms with the risk of collapse and the courtyard in front of it. Based on the conclusions of risk damage assessment, wood moisture decay is the main risk faced by the dwelling, so temperature and humidity were considered the physical quantities to be monitored.

With the consent and help of the owner of Dafudi, we placed four temperature and humidity sensors according to the preliminary investigation and evaluation, mainly in the damage/risk concentration area, the damage/risk potential area, and the important structural parts. To be specific, the corridor on the west side of the second floor of the backside, near the collapsed roof of the backside, on the wall of the first floor of the backside and by the window of the room on the north side of the courtyard.

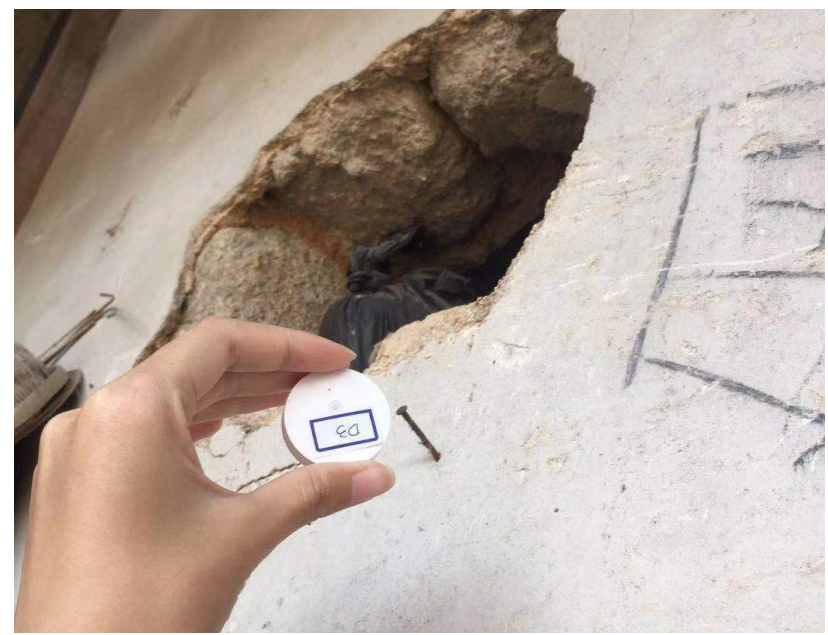

Figure 8. Humidity sensor used in Monitoring Dafudi

Since temperature and humidity mainly present daily cycle characteristics, the frequency of data collecting was set at 1 time per minute, and the real-time data can be viewed on Xiaomi APP.
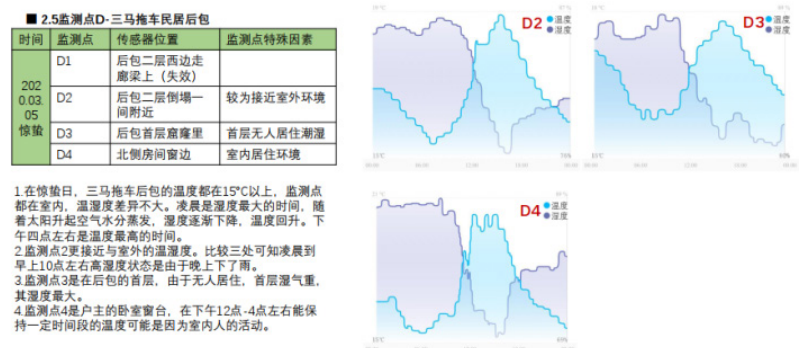

Figure 9. Monitoring interface of Dafudi

Meanwhile, we communicated fully with the villagers to explain the risks that the damages in the building may be faced with, gave instructions on the app, demonstrated the upload 
function, and encouraged them to upload photos and descriptions of the damages in time so that experts can make remote assessments based on the monitoring data.

4.3 Public Participation in creating a benign environment for the conservation: Constructing, promoting and utilizing the data management platform

The platform was used to manage and display the monitoring data, making it a medium that links villagers, professional forces, and architectural heritage. Our aim is to integrate architectural conservation into villagers' everyday life, raise their awareness of conservation, and create a benign environment for the conservation of village architectural heritage in order to form an organic conservation closed loop.

With the features of no download and registration, ready-to-use, easy development, multi-end access and free jumping, WeChat applets are considered more easy-to-use as display platforms. For this study, we choose the applet as a data management platform for village architectural heritage conservation and promote and utilize it.

4.3.1 Demand analysis and functional board design of the applet: The main purpose of the applet is to realize data management and display of village architectural heritage conservation. Thanks to the rapid popularization of smart phones in rural areas in recent years, mobile-end platforms can be easily used by villagers. To engage the villagers actively, a more relevant functional design and a lot of publicity and popularization work were needed.

Three types of users were considered.

1) Village managers (Villagers that help to manage the heritage): as assisting managers. The function of uploading information is needed to facilitate the management of village architecture conservation, cultural promotion and daily affairs.

2) Architectural conservation experts: to provide technical support for the conservation of village architecture. Multi-form knowledge output and convenient information collection and feedback functions are needed.

3) Villagers and tourists: the target users of the platform. Requires access to accurate village information as well as popular and useful architectural heritage conservation information.

Based on the analysis above, we built four major functional sections for the applet: village exclusive information section, village architectural conservation science section, damage survey section and key architectural heritage monitoring section (see figure). Each functional section can be used interactively to realize information exchange between village managers, experts, villagers and tourists.

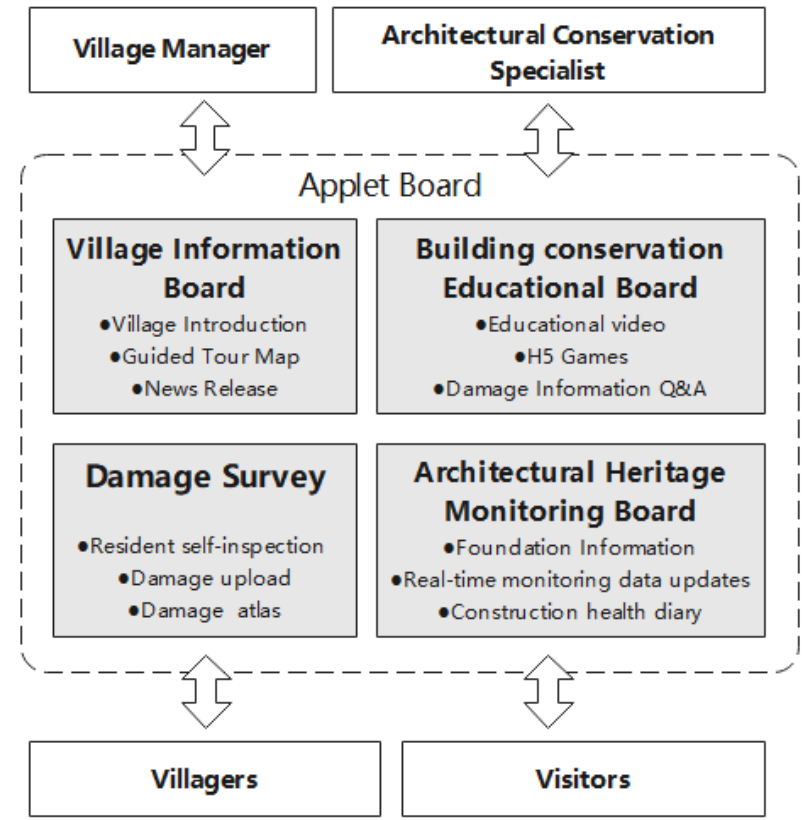

Figure 10. Boards of the platform

4.3.2 Developing the applet: To achieve the goal of building the platform at a low cost, convenient and quick way, we design the applet with the help of a modular applet development website, and complete the construction of the applet through module selection, button setting, page jump design, and page graphic information input. The applet for Shifeng Village, "The Beauty of Shifeng", was developed modularly using Faisco.com.
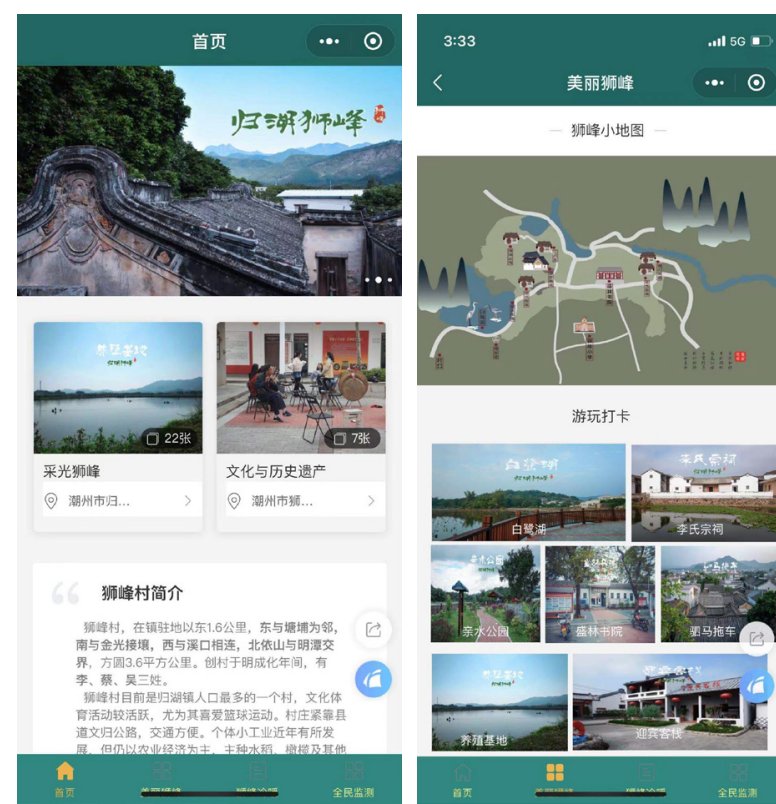

犯峰小地图

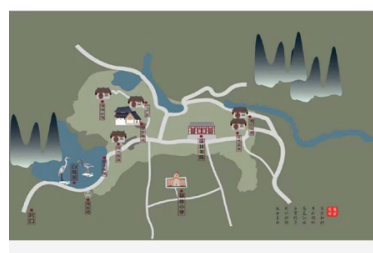

游玩打卡

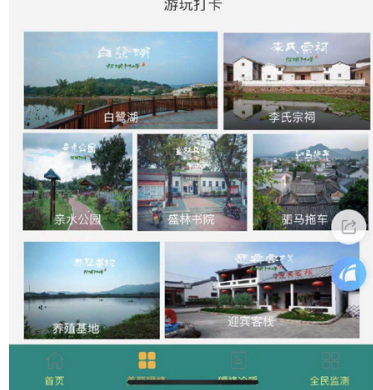



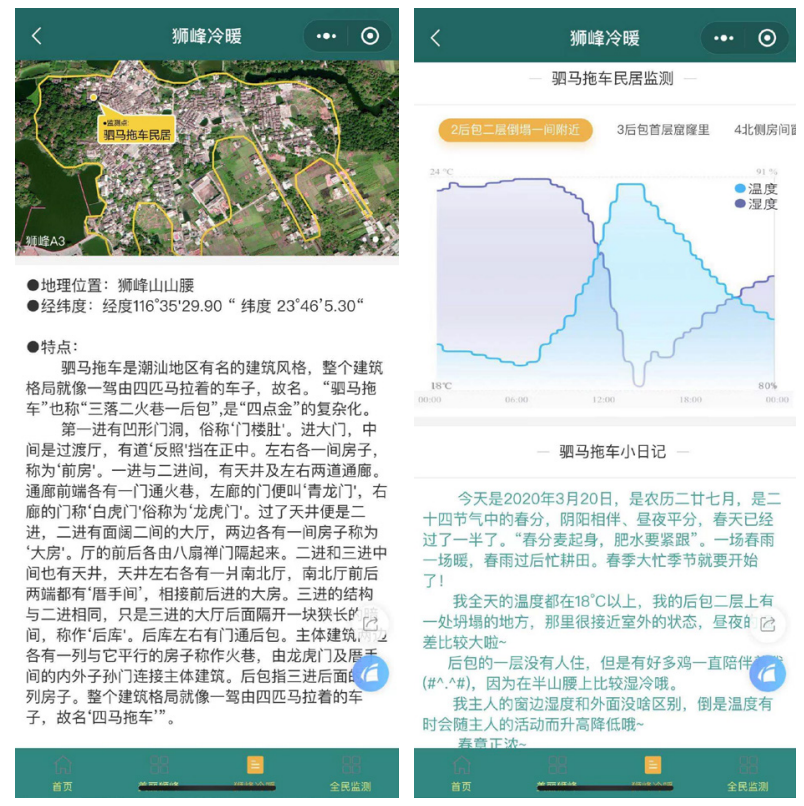

Figure 11. Interface of "The Beauty of Shifeng"

4.3.3 Promoting the conservation of architectural heritage: The implementation of the low-tech approach requires the participation of villagers. Promoting and publicizing the conservation of architectural heritage through applets is an important part of the benign loop. We launched and promoted the program at the Shenglin Academy in Shifeng Village in July. The presentation included an introduction to the functions of the data management platform, training for village managers, and the organization of online and offline games to engage villagers.

\section{RESULT AND DISCUSSION}

Conceptually, the project applies the frontier conservation concept of planned preventive conservation to rural area and reorganize the content and steps of it to emphasize the importance of prevention in the rural context. Methodologically, it takes advantage of the close connection between the blood and the local community in rural area to build a mechanism for public participation in conservation and uses accessible tools to explore a low-tech, low-cost and highly workable monitoring method.

In terms of the applicability of the conservation mode, we tried to reduce the threshold technically so as to be widely used in more villages. However, it should be noted that a key factor for this successful implementation is the support of government at all levels, from the municipality and town to which the village belongs, right down to the grassroots village council of the village.

The practice in Shifeng Village has been supported and recognized by the village and leaders of Chaozhou city, as a pilot project of rural digital conservation in the New Age Civilization Practice Station.

During the process of practice, we found that there is still much room for improvement in the conservation of rural architectural heritage.

1) Problems of public participation
One of the obstacles in public participation is that most of the professional architectural conservation knowledge is too obscure for villagers. The accessibility of knowledge should be considered more carefully.

Besides, on-site roadshows can only can only reach a limited number of people for a short period of time. A better mobilization effect may be achieved through door-to-door promotion of the administrator of the village.

\section{2) Applicability of tools and equipment}

The Xiaomi smart home sensors used in the monitoring of Dafudi do not support data export and the data can only be viewed on the Mi Home APP. The data, as a result, cannot be directly docked with the management platform, making the update of the monitoring module on the platform requiring a lot of extra labour.

Since the data transmission range of the current smart home system is limited and the connection is occasionally interrupted, more stable and intelligent sensors and system that can collect more data should be considered in the future.

\section{3) Effectiveness of conservation}

The interpretation of monitoring data is still a problem faced by all preventive conservation project. To further improve the work, we need to follow the development of the discipline to increase the effectiveness of data interpretation. In the practice of conservation and repair, establishing contact with local craftsmen in the future will help to realize the all-round conservation of villages through communication and training.

To sum up, the PPC work we constructed in Shifeng Village are technically and economically designed to lower the threshold and cost as much as possible in order to adapt to more villages. Meanwhile, the economic situation and heritage resource situation of the village itself will affect the progress and pace of implementation, but will achieve the basic preventive conservation goals as the work progresses. In mainland China, especially in rural areas, the implementation of PPC still requires the support of local governments and grassroots managers. The cost of research travel is currently supported by the local authority, as well as a small amount of government support for teaching and research as part of the university's mathematical education and research program.

Given the above, the planning preventive protection model of rural architectural heritage has a certain feasibility, and it is expected to bring new perspectives for the protection of other rural architectural heritage in the future.

\section{ACKNOWLEDGEMENTS}

This project was supported partially by the MOE Layout Foundation of Humanities and Social Sciences 20YJA760020.

\section{REFERENCES}

Accardo, G.,Altieri, A., Cacace, C., et al.2002.Risk map : a project to aid decision-making in the protection,preservation and conservation of Italian cultural Heritage.TOWNSEND J H,EREMIN K, ADRIAENS A. Conservation Science 2002:Papers from the Conference Held in Edinburgh, Scotland 22-24 May 2002.Los Angeles:Archetype Publications Ltd,2002:44-49

Accardo, G.,Giani, E.,Giovagnoli, A.,2003.The risk map of Italian cultural heritage.Journal of Architectural Conservation, $9(2), 41-57$ 
Core, M., 2009.MDDS(Monument Damage Diagnostic System):The development of an expert system as a survey and damage interpretation tool for the stability of masonry structures.Belgium: RLICC,K.U.LEUVEN,2009,14-17

Della Torre S, Wu, M.P., 2020. Italian Perspective on Preventive Conservation of Architectural Heritage. China Cultural Heritage., 96(2),12-24.

Rong, Q.W., 2020. The Generation and Progress of the International Preventive Conservation Networks of Architectural Heritage :Footprints of European Researchers and Practitioners. Study on Natural and Cultural Heritage ,5(1),88103.

Rong, Q.W., Zhang, J.R. ,2019. Preventive and Planned: On the Concept and Development of Preventive Conservation in International Architectural Heritage Studies. Architectural Journal .605(2),88-93.

Wu, M.P., 2011. Preventive Conservation of Architectural Heritage. Southeast University, Nanjing,China.

Wu, M.P., 2020. Preventive Conservation of Architectural Heritage: An Overview of the Theoretical Development and Practices in European. China Cultural Heritage., 96(2),59-78. 